\title{
Döviz Cinsi Krediler Bir “Döviz Riski” Azaltma Araci Mıdır? 2003-2018 Türkiye Analizi
}

\author{
Hakan Eryüzlüa, b, Sertaç Hopoğluc
}

\section{Özet}

Döviz kuru gelişmekte olan ekonomiler için önemli bir makro değişken olma özelliğini korumaktadır. Döviz kurunda meydana gelen dalgalanmalar özellikle yükselme yönünde olduğunda, gerek ülkedeki döviz borçluları gerekse ithal girdi ile çalışan firmalar için döviz riski yaratmaktadır. Döviz riskinin bilincinde olan yatırımcılar olası döviz riski için çeşitli aksiyonlar almaktadır. Çalışmada, ticari bankalar tarafından verilen krediler içerisinde yer alan döviz cinsi kredileri kullanan yatırımcıların, döviz riskinden korunmak için mi kredi çektikleri araştırılmıştır. Bu amaçla, Türkiye için 2003:1-2018:6 dönemi, ARDL eşbütünleşme ve Todo-Yamamoto (1995) nedensellik analizleri ile test edilmiştir. Test amaciyla ilgili dönemde aylık olarak ticari bankaların kredi kullanımları içerisinde döviz cinsi kredi oranları ve döviz kurunu temsilen de reel efektif döviz kuru kullanılmıştır. Sonuçlar, döviz kredisi kullanımının döviz riskinden korunma yolu olarak

\author{
Anahtar Kelimeler \\ Döviz Cinsi Krediler \\ Döviz Riski \\ ARDL Eşbütünleşme \\ Toda-Yamamoto nedensellik \\ Makale Hakkında \\ Geliş Tarihi: 03.12.2018 \\ Kabul Tarihi: 24.04.2020
}

Doi: $10.18026 /$ cbayarsos.491511 gerçekleşebileceğini göstermiştir.

\section{Are Foreign Exchange Loans Means Of Hedging Against "Foreign Exchange Risk?": An Analysis For Turkey, 2003-2018}

\begin{abstract}
Exchange rates are important macro variables for developing economies. Fluctuations in exchange rates, especially upward trending movements, creates a foreign exchange risk for both debtors and firms that use imported inputs in their operations. In consideration of this, investors take on various actions to avoid possible foreign exchange risks. Thus, this study investigates whether investors borrowing foreign exchange loans from commercial banks use such credits as a means of hedging against foreign exchange risk. In this respect, ARDL cointegration and Toda-Yamamoto (1995) causality analyses are employed to study the relationship between ratio of foreign exchange loans to the total loans granted by commercial banks and real effective exchange rate in turkey for the period 2003:1-2018:6. The results of the analysis indicate that foreign exchange loans can be taken out as a means of hedging against foreign exchange risk.
\end{abstract}

Keywords

Foreign Exchange Loans

Foreign Exchange Risk

ARDL Cointegration

Toda-Yamamoto Causality

About Article

Received: 03.12.2018

Accepted: 24.04 .2020

Doi: 10.18026/cbayarsos.491511

\footnotetext{
a İletişim Yazarı: hakan.eryuzlu@iste.edu.tr

b Dr. Öğr. Üyesi, İskenderun Teknik Üniversitesi, İşletme ve Yönetim Bilimleri Fakültesi Ekonomi Bölümü, ORCID: 0000-0003-3715-0021

c Dr. Öğr. Üyesi, İskenderun Teknik Üniversitesi, İşletme ve Yönetim Bilimleri Fakültesi Uluslararası Ticaret ve İşletmecilik Bölümü, ORCID: 00000002-9541-2352
} 


\section{Giriş}

Teknolojinin hızlı gelişmesi ile Dünya ekonomisi ve finansal piyasaların entegrasyonu artmış ve birbirlerini etkileme süreleri kısalmıştır. Yatırımcılar, piyasalar ile ilgili bilgilere çok daha çabuk ve düşük maliyetli şekilde ulaşabilmekte ve müdahale süreleri de çok kısa olmaktadır. $\mathrm{Bu}$ gelişmelere paralel olarak bankacılık sektöründeki araçlar çeşitlenmiş ve bu araçların yatırımcılar tarafından kullanımı artık daha kolay bir hale gelmiştir. Söz gelimi bir kredi kullanımı artık mobil telefonlardan dahi kolayca yapılabilmekte veya yatırımcılar hesaplar arası transferleri çok kısa sürelerde gerçekleştirebilmektedir.

Tüm bu gelişmelere rağmen bankacilık sektörünün en büyük gelir kaynağ1 ve en önemli finansal fonksiyonu kredi sağlayabilmesidir. Bankalar kredi kullanımını çeşitli teknolojiler ile kolaylaştırıp müşteri çekme gayreti içerisinde bu çok önemli işlevini yerine getirmektedir. Küreselleşen ekonomiye paralel olarak bankalar da artık uluslararasılaşmıştır. Birçok banka birçok ülkede açtıkları şubeler, satın aldıkları yerel bankalar veya birleşmeler yoluyla faaliyet göstermektedir. Her ne kadar bankalar bulundukları ülkenin yerli parası cinsinden işlemleri öncelikli olarak yapsalar da, yabancı paralar ile de işlemler gerçekleştirmektedirler. Döviz cinsi krediler olarak da isimlendirebileceğimiz yabancı para kredileri, 1980'lerin yeni kitlesel pazarlanan finansal ürünlerinden biriydi (Kingston, 1986, s.31). Günümüzde ise, bankalar açısından kayda değer bir finansal araçtır. Öyle ki, döviz cinsi mevduatlar Uruguay, Lübnan, Hirvatistan da yerel para cinsi mevduatlardan daha fazladır (Bozovic, 2009, s.32).

Yatırımcılar çok farklı nedenler ile dövize talep gösterebilirler. Dövize olan talep ise döviz kurunun oluşumunda etkili olmaktadır. Gelişmekte olan ülkelerde döviz kuru dalgalanmalarının iktisadi hayata etkisi literatürde çokça doğrulanan ve kabul edilen gerçektir. Döviz kurundaki ani ve sert artışlar yatırımcıları çoğu zaman olumsuz yönde etkilemektedir. Özellikle sanayisi ithalata dayalı bir ülkede dövizdeki sert artışlar üretimi olumsuz yönde etkilemekte ve döviz üzerinden ithalat yapan firmaların maliyetlerini şişirmektedir. Bu durumda bu tip ülkelerde döviz ile işlem yapan yatırımcının sürekli olarak döviz artış riski ile karşı karşıya olduğu bir gerçektir.

Gelişmekte olan bir ülke konumundaki Türkiye açısından döviz üretimde önemli bir değişkendir. Türkiye yarı mamul ve hammadde bakımından ve aynı zamanda teknoloji tabanlı üretim açısından yurtdışı bağımlılığı yüksek olduğundan üretimi arttırmak için daha fazla ithalata, dolayısıyla daha fazla dövize ihtiyaç duyulmaktadır. Bu durum dış ticaret rakamlarından da görülebilmektedir; 2015 yılı dış ticaret rakamlarına göre Türkiye'nin en çok ihracat yaptığı ilk beş fasıl, "motorlu kara taşıtları", "makineler", "kıymetli veya yarı kıymetli taşlar", "örme giyim eşyası" ve "elektrikli makine ve cihazlardır". Bu göstergeler ile beklenen durum net ihracat gelirlerinde de en çok bu fasıllardan pozitif girdi olmasıdır. Fakat net ihracat gelirleri incelendiğin de; sadece iki fasıldan net kazanç elde edilmektedir: "kıymetli veya yarı kıymetli taşlar" ve "örme giyim eşyası". Bununla beraber "motorlu kara taşıtları", "makineler", "elektrikli makine ve cihazlar" fasıllarından net zarar elde edilmektedir. Hatta "makineler" ve "elektrikli makine ve cihazlar" fasılları en çok zarar edilen fasıllar arasındadır (net ihracatları sırasıyla: -13,2 milyar dolar ve $-9,3$ milyar dolar. Bunlara karşın en çok kar edilen fasıl olan "örme giyim eşyası" faslının net ihracatı 8 milyar dolardır). Yakın tarihli bir araştırmada Kundak ve Aydoğuş (2018) Türkiye ekonomisi için kısa, uzun ve birim etkileri açısından dinamik panel veri analizi ile özellikle kısa dönemde döviz kurunda meydana gelen artışların, imalat sanayinde ithalat bağımlılığını arttırdığını tespit etmişlerdir. Çünkü döviz kurundaki artış ithal ara ve yatırım malları maliyetini yükseltmektedir. Kundak ve Aydoğuş 
(2018), uzun dönemde de kısa dönemdeki sonuçlara benzer olarak, sabit sermaye yatırımları, GSYİH ve döviz kurunda oluşan artışların imalat sanayinin dışa bağımlılı̆̆ını arttırıcı etkiler ortaya çıkardığını da bildirmektedirler.

Çalışmanın araştırma hipotezi; "gelişmekte olan ve döviz dalgalanmalarının risk taşıdığı bir ülkede, yatırımcılar/borçlular yerli paranın değer kaybetmesi veya döviz kurunun artması riskinde/durumunda ellerinde daha çok döviz bulundurma isteği ile döviz cinsi kredilere daha çok başvururlar. Böylece döviz arttığında veya bulunması zor olduğunda söz konusu krediler ile ihtiyaçlarını giderebilirler" olarak belirlenmiştir. Eğer araştırma hipotezi analiz sonucunda geçerli çıkar ise, döviz cinsi kredi verme oranı ve döviz kuru arasında eşbütünleşme ilişkisi var olmalıdır ve aynı zamanda kısa dönemde nedensellikte çıkması da beklenmelidir. Böylece, iktisadi birimlerin döviz cinsi kredi kullanma kararının arkasındaki nedenlerle ilgili literatüre katkıda bulunmak hedeflenmiştir.

Çalışmanın buradan sonraki bölümünde önce literatür hakkında bilgi verilmiş, devamında araştırma hipotezinin Türkiye geçerliliğini test etmek amacıyla, 2003-2018 dönemi ARDL eşbütünleşme ve Todo-Yamamato (1995) nedensellik analizleri ile test edilmiştir. Analizde ilgili dönemde aylık olarak ticari bankaların kredi kullanımları içerisinde döviz cinsi kredi oranları ve döviz kurunu temsilen de reel efektif döviz kuru kullanılmıştır. Çalışmanın son bölümünde de sonuçlar derlenmiştir.

\section{Literatür Özeti}

Çalışma da ele alınan ana hipotez ile ilgili yakın tarihli çalışmalardan biri, Do ve Vu (2018) tarafından literatüre sunulan çalışmadır. Do ve $\mathrm{Vu}$ (2018), döviz cinsinden kredilerin, kurumsal fonlamanın yanı sıra operasyonel bir risk yönetim aracı olduğunu ve yurt içi borçluların döviz kuru riskine maruz kalma riskinden korunmak için döviz cinsi kredileri kullandıklarını göstermişlerdir. Benzer şekilde Mora vd. (2013), Lübnan için yaptıkları çalışmalarında, yerel bankaların etkin olduğu bir ekonomideki birçok firmanın döviz cinsinden neden borçlandığını araştırmış ve sonuç olarak, döviz kuru riskinden korunan ihracatçıların döviz borcuna girmesinin daha olası olduğunu ve ayrıca, müşteriler ve tedarikçiler için kur riskinden geçerek kendilerini riskten koruduklarını savunmuşlardır. Aksi bir çalışmada Xu ve La (2015), Asya ekonomileri üzerine 2008 küresel krizi dönemi araştırması yapmışlardır. Bulgularında, döviz likiditesindeki daralmanın kısmen yerel para birimi cinsinden borçlanma ile ikame edildiğini tespit etmişlerdir. Döviz cinsi kredileri benzer şekilde kullanma nedenlerini araştıran, Buszko ve Krupa (2015), çalışmalarında Polonya ve Macaristan arasında karşılaştırmalı bir analiz yaparak, döviz cinsi kredileri gayrimenkul almak için kullanılma nedenini araştırmışlardır. Ayrıca, bu tür kredilerin her iki ülkede de borçlulara, bankacılık sektörlerine ve sistemik riske etkisi incelenmiştir.

Döviz cinsi krediler için başka araştırmalarda literatürde mevcuttur. Örneğin literatürde döviz cinsi kredilerin ekonomide yaratacağı riskler incelenmiştir. Bozovic vd. (2009), yerel para biriminin önemli ölçüde değer kaybetmesi durumunda, döviz cinsinden borç alanın ödeme kabiliyetinin önemli ölçüde azalabileceği ve borç verenin riske maruz kalmasına neden olabileceğini varsaymışlardır. Çalışmada, Bozovic vd. (2009) döviz cinsinden kredilerin döviz kuru riskinin temerrüt riskine nasıl dönüştüğü incelemişlerdir. Yabancı para birimli kredilerin ekonomik faaliyetlerin finansmanında baskın bir kaynak olduğu bir ekonomide, yerel para biriminin amortismanının daha yüksek temerrüt olasılıklarına, azalan kredi arzına ve azalan büyümeye yol açan bir olumsuz geri bildirim mekanizması oluşturduğu sonuçlarına 
ulaşmışlardır. Breuer vd. (2010), döviz kredisi portföyü örneğinde döviz kurunun, hem piyasa riski hem de kredi riski faktörü olarak düşünülebileceğini vurgulamışlardır. Piyasa riski faktörüdür, çünkü herhangi bir varsayılanın olmaması durumunda portföy değeri üzerinde bir etkisi vardır. Aynı zamanda, hem varsayılan olasılıklar hem de varsayılan kayıpların büyüklüğü üzerinde bir etkiye sahip olduğu için bir kredi riski faktörüdür şeklinde yorumlamışlardır. Beckmann vd. (2012), döviz cinsi kredilerin ekonomideki finansal kırılganlığı artırıp arttırmadığını test etmişlerdir. Bu çerçevede, hane halkının kredi borçlarının belirleyicilerini araştırmak için bir anket düzenlenmiş, Orta ve Doğu Avrupa ülkelerinde uygulanmıştır. Sonuçlarında, döviz cinsinden borçlanmanın finansal kırılganlık üzerinde ihmal edilmez bir etkisi olduğunu tespit etmişlerdir. Yeşin (2013), Bankacılık dışı sektöre verilen döviz cinsi kredilerin Avrupa'da belirgin bir şekilde yaygın olduğunu ve Avrupa bankacılık sektörlerine önemli bir döviz kuru kaynaklı kredi riski bulunduğunu belirtmiştir. Yeşin (2013) ayrıca, Avrupa'daki bankaların, döviz kurundan kaynaklanan kredi riskine karşı farkındalıklarını göstererek, yükümlülüklerden daha fazla yabancı para cinsinden varlıklarını sürekli olarak tuttuklarını da tespit etmiştir. Endresz ve Harasztosi (2014), döviz cinsinden kredilendirmenin yatırım üzerindeki etkisini araştırmışlardır. Macar firmaları üzerinde yaptıkları analizlerde, döviz cinsinden kredilendirme işleminin krizden önce daha büyük yatırımlara katkıda bulunup bulunmadığını ve durgunluk sırasında değer kaybının döviz kredisi olan firmalar için daha düşük yatırım oranıyla sonuçlanıp karşılanmadığını test etmişlerdir. Sonuçlar krizden önce döviz kurundaki artışın yatırım oranlarını artırdığını ve kriz sırasında, döviz cinsi kredileri olan şirketlerin yatırım oranlarının daha fazla düştügüün̈ göstermektedir. Beckmann ve Stix (2015), döviz cinsi kredilere olan talebin, bu tür kredilerden kaynaklanan döviz kuru riski ile ilgili bilgi eksikliğinden kaynaklanıp kaynaklanmadığını araştırmışlardır. Bunun içinde Orta ve Doğu Avrupa'da sekiz ülkede anket gerçekleştirmişlerdir. Çalışmanın sonucunda, döviz kuru riski hakkındaki bilginin kredi para birimi seçiminde güçlü bir etki yarattı̆̆ını tespit etmişlerdir.

Literatürde döviz cinsinden borçlanmanın nedenleri ve belirleyicileri üzerine çalışmalarda mevcuttur. Brown vd. (2011), çalışmalarında 2002-2005 yılları arasında, 25 geçiş ülkesinde 3101 firmaya verilen en son kredi bilgisine istinaden, küçük işletmelerin döviz cinsi borçlanmalarının firma ve ülke düzeyindeki belirleyicilerini incelemişlerdir. Sonuçlarında, döviz cinsinden borçlanmanın çok daha güçlü olduğunu tespit etmişlerdir. Ve yine bulgularında döviz cinsi kredileri alan perakende müşterilerin, yaygın olarak düşünüldüğünden farklı olarak, ilgili döviz risklerini karşılayacak şekilde daha donanımlı olduğunu göstermişlerdir. Öneri olarak ta politika yapıcıların, döviz cinsi kredileri engellemeye yönelik düzenlemeleri uygulamadan önce borç alanların özelliklerine daha yakından bakmalıdır olarak sunmuşlardır. Bogoev (2011), çalışmasında döviz cinsi kredi arz fonksiyonu için en önemli bankaya özgü özelliğinin banka büyüklüğü olduğunu bildirmekte, ancak yerel para cinsi krediler için hiçbir bankaya özgü özelliğinin önemli bir rolü olmadığını tespit etmiştir. Fidrmuc vd. (2013), Orta ve Doğu Avrupa ülkeleri üzerindeki çalışmalarında, döviz cinsinden kredilerin hane halklarının yerel para biriminin istikrarına ve yerel finansal kuruluşlara olan güven eksikliğinden kaynaklandığını tespit etmişlerdir. Ayrıca, bulgularına dayanarak döviz kredileri tüketim artışına katkıda bulunurken, aynı zamanda borçluların ve alacaklıların finansal savunmasızlığını da artırdığını savunmuşlardır. Bu durumun da, döviz cinsinden borçların yüksek oranda bulunduğu ülkelerin finansal istikrarını tehlikeye atabileceğini belirtmişlerdir. Cuaresma vd. (2014), Orta ve Doğu Avrupa'daki döviz kredilerinin belirleyicilerinin analizini etmişlerdir. Bunun için döviz cinsi kredi talebinin yedi 
belirleyicisini yaklaşık 800 tahmini katsayı sağlayan 21 çalışmanın sonuçlarını kullanmışlardır. Ortalama olarak, faiz oranı farklarının krediler için para birimi seçiminde etkili olmadığını ve böylece, döviz cinsinden krediler, sadece Orta ve Doğu Avrupa'daki borçluların talebinin bir sonucu olarak görünmediğini savunmuşlardır. Sonuç olarak, arz faktörlerinin (yabancı para mevduat ve asgari varyans portföy oran1), yabanc1 para cinsinden kredilerin talep faktörlerinden (faiz oranı farkları) daha önemli bir rol oynadığını tespit etmişlerdir. Brown vd. (2014), banka finansmanı yapısının ve menkul kıymetleştirme faaliyetlerinin iş kredilerinin para birimi cinsini nasıl etkilediğini incelemişlerdir. Bulgularında, yabancı para cinsinden kredilendirmenin, kısmen, varlıkların para birimi yapısına uygun olarak yükümlülüklerin yerine getirilmesi ile ilgili banka arzından kaynaklandığını tespit etmişlerdir. Gelişmekte olan Avrupa ülkelerinde yabancı para cinsinden borçlanmanın arz faktörleri tarafından yönlendirilemeyeceğini düşündüklerinden, sadece talep tarafını ele alan önlemler yabancı para borçlanmayı frenlemek için yeterli olmayabilir görüşünü savunmuşlardır. Skibińska (2018), en büyük üç orta ve doğu Avrupa ülkesi (Polonya, Çek Cumhuriyeti ve Macaristan) için bir panel VAR modeli kullanarak, yurtiçi ve yabancı para cinsinden kredilerin parasal ve döviz kuru şoklarına tepkisindeki farklılıkları incelemiştir. Sonuç olarak, Polonya ve Macaristan'da para politikası sıkılaşmasına tepki olarak yerel para cinsinden kredilerdeki düşüşe ve döviz kredisi artışına işaret ederek, döviz kuru borcunun varlığının para politikasının aktarımını zayıflattığını tespit etmiştir. Vonnák (2018), Kriz zamanlarında farklı para birimlerinde borç alan firmaların döviz performanslarının döviz kuru seçimine etki derecelerini araştırmıştır. Ayrıca, Macaristan üzerine yaptığı araştırmada, yerel para birimi borçlularına kıyasla, yabancı para borçluların daha kötü kredi performansına katkıda bulunan faktörleri ayrıştırmayı amaçlamıştır. Sonuç olarak, kredi ödememe durumunun, döviz cinsi kredi veren kurumlardan ziyade kredi alan borçlulardan kaynaklandığına ve önlemlerin özellikle borçlular yönünde alınması gerektiğine işaret etmiştir.

\section{Yöntem}

\section{Verilerin Toplanması ve Analizi}

Çalışmada, 2003:01-2018:06 arası aylık olarak reel efektif döviz kuru (REK) ve döviz cinsi kredilerin toplam krediler içindeki kullanım oranı olan döviz cinsi kredi oranı (DKO) serileri kullanılmıştır. Reel efektif döviz kuru Türkiye Cumhuriyet Merkez Bankası'ndan, döviz cinsi kredi oranı ise, Bankacılık Düzenleme ve Denetleme Kurulu'nun aylık veri bültenlerinden elde edilmiştir. REK serisi Türkiye'nin diş ticarette en çok ilişkide olduğu ülkelerin para birimlerinin, fiyat etkisinden arındırılmış, ağırlıklı ortalama değerlerini veren bir gösterge olduğu için seçilmiştir. Böylece Türkiye'de işlem gören tüm dövizlerin (yabancı paraların) ortak hareketi analizde dikkate alınmıştır. REK'deki değişimlere karşı ana hipotez olan "gelişmekte olan ve döviz dalgalanmalarının risk taşıdığı bir ülkede, yatırımcılar/borçlular yerli paranın değer kaybetmesi veya döviz kurunun artması riskinde/durumunda ellerinde daha çok döviz bulundurma isteği ile döviz cinsi kredilere daha çok başvururlar. Böylece döviz arttı̆̆ında veya bulunması zor olduğunda söz konusu krediler ile ihtiyaçlarını giderebilirler" hipotezi testi içinde tüm krediler içerisinde kullanılan döviz cinsi kredilerin oranı serisi seçilmiştir.

\section{Araştırma Modeli}


Çalışmada, 2003:01-2018:06 arası aylık olarak reel efektif döviz kuru (REK) ve döviz cinsi kredilerin toplam krediler içindeki kullanım oranı olan döviz cinsi kredi oranı (DKO) serileri kullanılmıştır. Reel efektif döviz kuru Türkiye Cumhuriyet Merkez Bankası'ndan, döviz cinsi kredi oranı ise, Bankacılık Düzenleme ve Denetleme Kurulu'nun aylık veri bültenlerinden elde edilmiştir. REK serisi Türkiye'nin diş ticarette en çok ilişkide olduğu ülkelerin para birimlerinin, fiyat etkisinden arındırılmış, ağırlıklı ortalama değerlerini veren bir gösterge olduğu için seçilmiştir. Böylece Türkiye'de işlem gören tüm dövizlerin (yabancı paraların) ortak hareketi analizde dikkate alınmıştır. REK'deki değişimlere karşı ana hipotez olan "gelişmekte olan ve döviz dalgalanmalarının risk taşıdığı bir ülkede, yatırımcılar/borçlular yerli paranın değer kaybetmesi veya döviz kurunun artması riskinde/durumunda ellerinde daha çok döviz bulundurma isteği ile döviz cinsi kredilere daha çok başvururlar. Böylece döviz arttığında veya bulunması zor olduğunda söz konusu krediler ile ihtiyaçlarını giderebilirler" hipotezi testi içinde tüm krediler içerisinde kullanılan döviz cinsi kredilerin oranı serisi seçilmiştir.

Serilerin durağanlık analizleri ADF (Augmented Dickey Fuller), PP (Phillips Perron), ZA (Zivot Andrews) birim kök testleri kullanılmıştır. Birim kök tsti sonuçları tablo 1'deki gibidir;

Tablo 1. Birim Kök Testi Sonuçları

\begin{tabular}{lcccc}
\hline & \multicolumn{3}{c}{ Birim Kök Testi } & - \\
\hline Değişken & ADF & PP & ZA & Sonuç \\
\hline REK & $\mathrm{I}(1)^{* *}$ & $\mathrm{I}(1)^{* *}$ & $\mathrm{I}(1)^{* *}$ & $\mathrm{I}(1)$ \\
\hline DKO & $\mathrm{I}(0)^{* *}$ & $\mathrm{I}(0)^{* *}$ & $\mathrm{I}(0)^{*}$ & $\mathrm{I}(0)$ \\
\hline
\end{tabular}

*Sabitli

**Sabitli ve Trendli

Tablo.1'e göre, reel efektif döviz kuru 1. farkında, döviz cinsi kredi oranı ise, seviyesinde durağan çıkmıştır. Seriler farklı seviyelerde durağan çıktığ1 için aralarındaki eşbütünleşme analizi için ARDL sınır testi seçilmiştir.

Değişkenler arasında eşbütünleşme ilişkisinin olup olmadığı belirlemek için kullanılan yöntemlerden biri ARDL sınır testidir. Pesaran ve Shin tarafından 2001 yılında geliştirilen test, aşağıdaki gibi (1) numaralı regresyon denkleminde y bağımlı değişken ve $\mathrm{k}$ adet $\mathrm{Xj}_{\mathrm{j}}$ ler bağımsız değişken olmak üzere ARDL sınır testidir.

$\Delta y_{t}=\theta_{0}+\sum_{i=1}^{p} \gamma_{i} \Delta y_{t-1}+\sum_{j-1}^{k} \sum_{i=0}^{p} \delta_{j, i} \Delta X_{j, t-i}+\alpha_{0} y_{t-1}+\sum_{i=0}^{p} \alpha_{j} \Delta X_{j, t-1}+\varepsilon_{t}$

(1) denkleminde; $\varepsilon_{t}$, hata terimini; $\mathrm{p}$, değişkenlerin gecikme uzunluğunu; $\theta_{0}$, sabit terimi ve $\gamma_{i}, \delta_{j, i}, \alpha_{0}, \alpha_{j}$ ilgili değişkenlerin katsayılarını temsil etmektedir. (1) numaralı regresyon modelinde değişkenler arasında eşbütünleşme ilişkinin var olup olmadığını belirlemek için $F$ istatistiği kullanılır ve değişkenler arasında sınır testine ilişkin $\mathrm{H} 0$ hipotezi, $\alpha$ 'ların sıfıra eşit olduğunu gösteren hipotezdir. 
Pesaran ve diğerleri (2001), tüm değişkenlerin I(0) ya da I(1) oldukları iki uç durum için sırasıyla alt ve üst sınır tablo kritik değerlerini oluşturmuşlardır. Hesaplanan F istatistiği I(1) üst sınır değerinden büyük çıkması durumunda değişkenler arasında eşbütünleşme ilişkisi vardır diyebiliriz. Dolayısıyla testin uygulanabilmesi için değişkenlerin I(2) seviyesinin altında durağan olmaması gerekmektedir. Aynı derecede durağan olmasalar dahi ARDL uygulanabilmesi için I(2) seviyesinin altında durağan olmaları yeterlidir. Testin bir başka özelliği değişken sayısının az olmasında dahi testin uygulanabilme yeteneğidir.

Değişkenler arasında eşbütünleşme ilişkisi bulunursa değişkenler için uzun dönem esneklik katsayılarının tahmini için aşağıdaki ARDL modeli kullanılır.

$y_{t}=\emptyset_{0}+\sum_{i=1}^{p} \theta_{i} y_{t-i}+\sum_{j=1}^{k} \sum_{i=0}^{q_{j}} \rho_{j, i} X_{j, t-i}+\varepsilon_{t}$

(2) denkleminde, $\varepsilon_{t}$, hata terimini; $\mathrm{p}$, bağımlı değişkenin gecikme uzunluğunu; $\rho_{j, i}, \mathrm{j}^{\prime}$ ninci bağımsız değişken bağımsız değişkenin gecikme uzunluğunu; $\emptyset_{0}$, sabit terimi ve $\theta_{i}, \rho_{j, i}$ ilgili değişkenlerin katsayılarını ifade etmektedir. Bağımsız değişken $X_{j}$ için uzun dönem esneklik katsayısı $\epsilon_{j},(2)$ nolu denklemin parametreleri kullanılarak hesaplanır;

$\beta_{j} \frac{\sum_{t=1}^{q, j} \rho_{j, i}}{1-\sum_{i=1}^{p} \theta_{j}}$

Kısa dönem etkileri görmek için ARDL hata düzeltme modeli (ARDL-HDM) aşağıda gösterildiği gibidir.

$\Delta y_{t}=\pi_{0}+\sum_{i=1}^{p} \lambda_{i} \Delta y_{t-1}+\sum_{j=1}^{k} \sum_{i=0}^{q_{j}} \omega_{i} \Delta X_{j, t-i}+\psi E C_{t-1}+\varepsilon_{t}$

(3) numaralı ARDL-HDM'de; EC, hata düzeltme terimini; $\pi_{0}$, sabit terimi; $\omega_{i}, \lambda_{i}$ ilgili değişkenlerin katsayılarını ve $\psi$, modelin dengeye gelme hızını gösterir. EC aşağıdaki uzun dönemden denklemi olan (4)'den hesaplanır;

$E C_{t}=y_{t}-\alpha-\sum_{j=1}^{k} \beta_{j} X_{j, t-i}$

(4) numaralı ARDL-HDM'de ECt-1 hata düzeltme teriminin katsayısının, 0 ile -1 arasında bir değer alması ve bu katsayının istatistiki olarak anlamlı olması gerekmektedir. Literatürde katsayının eksi değer alması ve anlamlı olmasının yeterli olduğu görüşleri de mevcuttur.

Değişkenler arasındaki nedensellik ilişkileri ise, Toda-Yamamoto(1995) nedensellik testi kullanılmıştır. Klasik Granger nedensellik testinde, serilerin durağan olması koşulu bulunmaktadır. Ayrıca durağan olmayan serilerin aralarında herhangi bir eşbütünleşme ilişkisi olması halinde VAR değil hata düzeltme modeli olan VECM modeller üzerinden Granger nedensellik testi yapılmaktadır. Toda-Yamamoto(1995) nedensellik bu iki durumun dikkate alınmadığı daha esnek bir testtir. Toda-Yamamoto(1995) nedensellik testinde, VAR modelin gecikme uzunluğu (k) ve analize alınan serilerin en büyük durağanlık mertebesini (dmax) dikkate alarak k+ dmax boyutunda bir VAR model kurulmaktadır. Söz konusu model aşağıdaki denklemlerden oluşmaktadır; 
$Y_{t}=\alpha_{10}+\sum_{i=1}^{k} \alpha_{1 i} X_{t-i}+\sum_{i=1}^{k} \beta_{1 i} Y_{t-i}+\sum_{j=k+1}^{d \max } \vartheta_{1 i} X_{t-i}+\sum_{j=k+1}^{d \max } \theta_{1 i} X_{t-i}$

$X_{t}=\alpha_{20}+\sum_{i=1}^{k} \alpha_{2 i} X_{t-i}+\sum_{i=1}^{k} \beta_{2 i} Y_{t-i}+\sum_{j=k+1}^{d \max } \vartheta_{2 i} X_{t-i}+\sum_{j=k+1}^{d \max } \theta_{2 i} X_{t-i}$

Model, X, Y'nin Granger nedeni değildir temel hipotezi testleri ile sonuçlandırılmaktadır. Buna göre birinci denklemde, (6) nolu denklemde $\propto_{-} \_1=0$ hipotezini Wald testi ile sinanır. Analizde Wald testi k serbestlik dereceli Ki-kare dağılımına uymaktadır.

\section{Bulgular}

Reel efektif döviz kuru (REK) - döviz cinsi kredi oranı (DKO) eşbütünleşme analizi; ARDL sınır testi yapılmış ve F istatistiğine göre sonuçları tablo 2' de sunulmuştur;

Tablo 2. ARDL Sınır Testi Sonuçları

\begin{tabular}{lccr}
\hline F istatistiği & K (gecikme) & I(0) alt sınır & I(1) üst sınır \\
\hline $\mathbf{1 9 . 9 0 2 4}$ & 1 & $3.94(\% 1)$ & $5.58(\% 1)$ \\
\hline
\end{tabular}

F istatistiği üst sınırdan daha büyük olduğu için, değişkenler arasında uzun dönemli ilişki olmadığını gösteren temel hipotez reddedilir. ARDL modelinde maksimum gecikme uzunluğu 4 verilerek ARDL kısa ve uzun dönem tahmin edilmiş ve sonuçları aşağıdaki tabloda sunulmuştur.

Tablo 3. Kısa Dönem ARDL Hata Düzeltme Modeli

\begin{tabular}{lcr}
\hline Değişken & Katsayı & Std Hata (olasılık) \\
\hline Hdt(-1) & -0.0522 & $-7.7701(0.0000)$ \\
\hline
\end{tabular}

Kısa dönem sonuçlarına göre değerlendirmede önemli sonuçlardan biriside hata düzeltme katsayısını temsil eden "Hdt(-1)" değeridir. Değerin 0 ile -1 arasında çıkması hata düzeltme mekanizmasının çalıştığını göstermektedir. Yani kısa dönemdeki sapmalar uzun dönemde dengeye gelmektedir.

ARDL modeli için uzun dönem sonuçları da aşağıdaki gibidir;

Tablo 4. Uzun Dönem ARDL Hata Düzeltme Modeli

\begin{tabular}{lcr}
\hline Değişken & Katsayı & Std Hata (olasıllk) \\
\hline REK & -0.0030 & $31.8693(0.0098)$ \\
\hline C & 0.6003 & $3155.79(0.0000)$
\end{tabular}

Uzun dönem sonuçlarına göre reel efektif döviz kuru istatiksel olarak anlamlı çıkmıştır. Döviz kurunun bağımlı değişken olan döviz cinsi kredi oranı üzerindeki etkisi negatiftir. Yani 
bağımlı değişken ile aralarında ters yönlü bir ilişki mevcuttur. Bunun anlamı, reel efektif döviz kuru artarken (yani Türk lirası değer kazanırken) döviz cinsi kredi oranı azalmaktadır. Tersi durumda yani döviz değer kazandığında ise, döviz cinsi kredi oranı artmaktadır.

Reel efektif döviz kuru ve döviz cinsi kredi oranı arasındaki nedensellik sonuçları Tablo 5'de sunulmuştur:

Tablo 5. Reel Efektif Döviz Kuru ve Döviz Cinsi Kredi Oranı Nedensellik

\begin{tabular}{lccr}
\hline REK $\rightarrow$ DKO & dMAX & Anlamlılık & Sonuç \\
\hline DKO $\rightarrow$ REK & 3 & 0.1126 & Nedensellik yok \\
\hline
\end{tabular}

Tablo 5' de verilen sonuçlara göre reel efektif döviz kurundan, döviz cinsi kredi oranına doğru nedensellik yok iken, döviz cinsi kredi oranından, reel efektif döviz kuruna nedensellik tespit edilmiştir.

\section{Sonuç ve Öneriler}

İktisadi birimler çok çeşitli nedenlerle döviz talep edebilirler. İster yatırım ister birikim amaçlı olsun tüm talepler döviz piyasasında değerlendirilir ve döviz kurunun oluşumuna etki eder. Döviz kurları ise, teknolojinin ilerlemesi ile özellikle gelişmekte olan ülkeler için mutlaka dikkate alınması gereken önemli bir iktisadi değişkendir. Döviz kurunda meydana gelen dalgalanmalar en basit ilişkide ihracat ve ithalatı o da üretimi etkilemektedir. Özellikle sanayisi ithalata dayalı bir ülkede dövizdeki sert artışlar üretimi olumsuz yönde etkilemekte ve döviz üzerinden ithalat yapan firmaların maliyetlerini şişirmektedir. Bu durumda bu tip ülkeler de döviz ile işlem yapan yatırımcının sürekli olarak döviz artış riski ile karşı karşıya olduğu bir gerçektir.

Türkiye açısından da döviz üretimde önemli bir değişkendir. Türkiye'de sanayinin ve teknoloji-yoğun üretimin ithalat bağımlılığı yüksek olduğundan daha fazla dövize (ithalata) ihtiyaç duyulmaktadır. Bu durumda da döviz kurundaki ani artışlara, yani döviz riskine, karşı yatırımcılar bazı tedbirler almak isteyebileceklerdir. Çalışmanın araştırma hipotezi de bu tedbirlerden biri olabileceği düşüncesi ile "gelişmekte olan ve döviz dalgalanmalarının risk taşıdığı bir ülkede, yatırımcılar/borçlular yerli paranın değer kaybetmesi veya döviz kurunun artması riskinde/durumunda ellerinde daha çok döviz bulundurma isteği ile döviz cinsi kredilere daha çok başvururlar. Böylece döviz arttığında veya bulunması zor olduğunda söz konusu krediler ile ihtiyaçlarını giderebilirler" olarak belirlenmiştir.

$\mathrm{Bu}$ amaçla reel efektif döviz kuru ve ticari bankalar tarafından verilen kredi tutarları içerisinde yabancı kaynaklı paralar üzerinden verilen döviz kredileri oranları arasındaki ilişki 2003-2018 dönemi aylık veriler kullanılarak analiz edilmiştir. Öncelikli olarak seriler arasında uzun dönemli beraberliği incelemek amacıyla eşbütünleşme testi yapılmıştır. Eşbütünleşme testi sonucu; anlamlı bir eşbütünleşme tespit edilmiştir. Ayrıca eşbütünleşme testinde döviz kurunun bağımlı değişken olan döviz cinsi kredi oranı üzerindeki etkisi negatif tespit edilmiştir. Bu durumda reel efektif döviz kuru artarken (yani Türk lirası değer kazanırken) döviz cinsi kredi oranı azalmaktadır. Tersi durumda yani döviz değer kazandığında ise, döviz 
cinsi kredi oranı artmaktadır. Bu sonuç araştırma hipotezinin doğruluğunu göstermektedir. Yani Türkiye'de dövizin değer kazanması döviz cinsi kredi çekilme oranını arttırmaktadır. Söz konusu ilişki ise, katsayıların küçüklüğü nedeniyle çok önemli ölçüde bir değişiklik yaratmamaktadır. Fakat yine de Türkiye'de döviz kredileri döviz riski azaltma aracı olabilmektedir. Yani döviz artışına karşı elinde döviz bulundurmak isteyen yatırımcılar döviz kredisi çekebilmektedirler. Bu durumda da döviz talebi artacağından dövizdeki artış devam edebilecektir. Söz konusu artış durumu ihracat başta olmak üzere birçok makroekonomik değişken üzerinden etkili olacağından, politika yapıcıların döviz cinsi krediler konusundaki düzenlemeleri döviz kontrolleri açısından işe yarayacak bir araç olabilecektir. Bu noktada şöyle bir öneri de getirilebilir; yabancı ticari bankalardan döviz kredisi alımının azaltılması (özellikle Türk ekonomisinin orta vadeli pozisyonu olumluyken) piyasada olumlu etkiler yapabilir.

Nedensellik analizinde eşbütünleşme analizinde ortaya çıkan uzun dönemli etkileşim olan döviz kurundan, döviz kredisi oranına kısa dönemli nedensellik çıkmamıştır. Bu durumda yatırımcının "döviz riski azaltma" aracı olarak döviz kredisi çekme düşüncesinin kısa dönemde değil uzun dönemli periyotlarda aldığı bir karar olduğunu göstermektedir. Yani yatırımcı dövizdeki dalgalanmaları takip etmekte ve ani şokları değil zaman içerisindeki artışı beklediğini göstermektedir. Fakat nedensellik analizinin diğer tarafında, durum daha değişik yorumlanabilir. Çünkü kısa dönem için döviz kredi oranın artması sonucu döviz kuru etkilenmektedir. Bu şunu göstermektedir ki, ticari bankalar tarafından verilen döviz kredileri, döviz piyasasını etkileyebilecek büyüklüktedir.

\section{Kaynakça}

Beckmann, E., Fidrmuc, J., \& Stix, H. (2012). Foreign currency loans and loan arrears of households in Central and Eastern Europe (No. 181).

Beckmann, E., \& Stix, H. (2015). Foreign currency borrowing and knowledge about exchange rate risk. Journal of Economic Behavior E Organization, 112(1), 1-16.

Bogoev, J. (2011). What drives bank lending in domestic and foreign currency loans in a small open transition economy with fixed exchange rate? The case of Macedonia. Comparative Economic Studies, 53(2), 307-331.

Božović, M., Urošević, B., \& Živković, B. (2009). On the spillover of exchange rate risk into default risk. Economic Annals, 54(183), 32-55.

Breuer, T., Jandačka, M., Rheinberger, K., \& Summer, M. (2010). Does adding up of economic capital for market-and credit risk amount to conservative risk assessment?. Journal of Banking \& Finance, 34(4), 703-712.

Brown, M., Ongena, S., \& Yeşin, P. (2011). Foreign currency borrowing by small firms in the transition economies. Journal of Financial Intermediation, 20(3), 285-302.

Brown, M., Kirschenmann, K., \& Ongena, S. (2014). Bank funding, securitization, and loan terms: Evidence from foreign currency lending. Journal of Money, Credit and Banking, 46(7), 1501-1534.

Buszko, M., \& Krupa, D. (2015). Foreign currency loans in Poland and Hungary-a comparative analysis. Procedia Economics and Finance, 30(2), 124-136. 
Cuaresma, J. C., Fidrmuc, J., \& Hake, M. (2014). Demand and supply drivers of foreign currency loans in CEECs: A meta-analysis. Economic Systems, 38(1), $26-42$.

Do, V., \& Vu, T. (2018). The additional cost of hedging in foreign currency loans. Australian Journal of Management, 43(2), 305-327.

Endrész, M., \& Harasztosi, P. (2014). Corporate foreign currency borrowing and investment: The case of Hungary. Emerging Markets Review, 21(1), 265-287.

Fidrmuc, J., Hake, M., \& Stix, H. (2013). Households' foreign currency borrowing in Central and Eastern Europe. Journal of Banking \& Finance, 37(6), 1880-1897.

Kingston, G. (1995). The foreign currency loans affair: an economist's perspective. Australian Economic Papers, 34(64), 31-49.

Kundak, S., ve İ. Aydoğuş, (2018). Türkiye' de İmalat Sanayinin İthalata Bağımlılığının Analizi, Gaziantep University Journal of Social Sciences, 17 (1), 252-266.

Mora, N., Neaime, S., \& Aintablian, S. (2013). Foreign currency borrowing by small firms in emerging markets: When domestic banks intermediate dollars. Journal of Banking $\mathcal{E}$ Finance, 37(3), 1093-1107.

Pesaran, M. H., Shin, Y., \& Smith, R. J. (2001). Bounds testing approaches to the analysis of level relationships. Journal of applied econometrics, 16(3), 289-326.

Skibińska, M. (2018). Transmission of monetary policy and exchange rate shocks under foreign currency lending. Post-Communist Economies, 30(4), 506-525.

Toda, H. Y., \& Yamamoto, T. (1995). Statistical inference in vector autoregressions with possibly integrated processes. Journal of econometrics, 66(1-2), 225-250.

Vonnák, D. (2018). Why do firms default on their foreign currency loans? The case of Hungary. Journal of International Money and Finance, 86(1), 207-222.

Yesin, P. (2013). Foreign currency loans and systemic risk in Europe (No. 13.06). Working Paper, Study Center Gerzensee.

Xu, Y., \& La, H. A. (2015). Foreign banks and international shock transmission: Does bank ownership still matter?. Journal of International Financial Markets, Institutions and Money, 38(1), 200-216. 